\title{
Experimental Investigation of Some Heavy Metals in the Muscle Tissue of Cultured African Catfish (Clarias gariepinus)
}

\author{
${ }^{1}$ Okwuosa Obinna Ben, ${ }^{2}$ Amadi Ibiam Christina O. and ${ }^{3}$ Omovwohwovie Emmanuel E \\ ${ }^{1}$ Department of Science Laboratory Technology, Akanu Ibiam Federal Polytechnic, Unwana \\ ${ }^{2}$ Department of Fisheries and Aquaculture, Ebonyi State University, Nigeria \\ ${ }^{3}$ Department of Fisheries Technology Federal Polytechnic Ekowe Bayelsa State, Nigeria
}

\begin{abstract}
Oftentimes, the environmental scientist believes that heavy metal contamination of aquatic ecosystem is related only to fishes in aquatic environment. The present study was therefore undertaken to investigate the bioaccumulation of Manganese (Mn), Cobalt (Co), Mercury (Hg), Arsenic (As), Chromium (Cr) and Nickel (Ni) in the muscle tissue of Cultured African Catfish (Clarias gariepinus). A total of two (2) fish were used (male and female) weighing $390 \mathrm{~g}$ and 310g. They were sacrificed and all the internal organs were removed and was oven dried at initial temperature of $105^{\circ} \mathrm{c}$ and later adjust to $65^{\circ} \mathrm{c}$ until a constant weight was obtained. The samples were ground and were digested with tri acid mixture ( $\left.\mathrm{HNO}_{3}: \mathrm{HCL}: \mathrm{H}_{2} \mathrm{SO}_{4}\right)$. Digestion continued until the liquor become clear. The samples were analyzed using Dez Elmer Analyst 300 Atomic Spectroscopy (AAS). The result showed that Mn recorded $896.94 \pm 0.577 \mathrm{mg} / \mathrm{l}$; Co $78.10 \pm 0.577 \mathrm{mg} / \mathrm{l}$; and $\mathrm{Ni}, 78.725 \pm 0.578 \mathrm{mg} / \mathrm{l}$ in feed 1 and $\mathrm{Mn}$ recorded $506.823 \pm 1.155 \mathrm{mg} / \mathrm{l}$; Co $32.499 \pm 0.577 \mathrm{mg} / \mathrm{l}$; $\mathrm{Hg}, 0.001 \pm 0.00001 \mathrm{mg} / \mathrm{l} ; \mathrm{As}, 0.006 \pm 0.0000 \mathrm{mg} / \mathrm{l} ; \mathrm{Cr}, 122.794 \pm 0.577 \mathrm{mg} / \mathrm{l}$. and Ni $56.180 \pm 0.578 \mathrm{mg} / \mathrm{l}$ in feed 2. The result of the muscle tissue of male and female C.gariepinus shows the present of heavy metals at different concentration and the highest concentration was observed in female recorded $\mathrm{Ni}(44.200 \pm 0.5774 \mathrm{mg} / \mathrm{l})$ and the lowest observed in male recorded in $\mathrm{Cr}(-0.007 \pm 0.0001 \mathrm{mg} / \mathrm{l})$. There was a significant difference $(P>0.05)$ among male and female C.gariepinus. This study has proved the availability of $\mathrm{Mn}, \mathrm{Co}, \mathrm{Hg}, \mathrm{As}, \mathrm{Cr}$ and $\mathrm{Ni}$ in the muscle tissue of C.gariepinus and also in the water and feeds used in culture the fish. This metal concentration observed in muscle tissue, feeds and water was beyond the maximum permissible limit by WHO/FAO and NOAA for human consumption contrary to most view that bioaccumulation of heavy metals is related to environmentally polluted water. Based on these findings, it is recommended that proper quality control analysis should be carried out in the cultured fish to determine its safety.
\end{abstract}

Keywords: Aquatic ecosystem, Bioaccumulation, Heavy Metals, African Catfish.

\section{INTRODUCTION}

Fish are widely consumed in many parts of the world by humans and polluted fish may endanger human health (Sen $e t$ al., 2011). Metals are non-biodegradable and consider as major environmental pollutants causing cytotoxic, mutagenic and carcinogenic effects in animals (Staniskiene et al., 2006). It is important to examine the toxic effects of metals on fish since they constitute an important link in food chain and their contamination by metal causes imbalances in aquatic system (Das et al., 2017) now in commercial pond via the feed.

The presence of higher amount of heavy metals in any part of the body will induce changes in biochemical metabolisms, serum biochemical changes, histopathological changes and other induced stresses (Halla et al., 2021).

Metal bioaccumulation is influenced by multiple routes of exposure (diet and solution) and geochemical effects on bioavailability (Bawuro et al., 2018). As metals are not metabolized, bioaccumulation of metals and metalloids is of particular value as an exposure indicator. 
Okwuosa, (2011) have shown that the cultured fishes are most patronised (most consumed) due to their availability and price friendliness. It is important to examine the toxic effects of metals on fish since they constitute an important link in food chain and their contamination by metal causes imbalances in aquatic system (Duruibe, et al.,2007) now in commercial pond via the feed. Catfish have become the most consumed fish food by man, adequate measures should be taken to avoid accumulating excess heavy metals such Manganese (Mn), Cobalt (Co), Mercury (Hg), Asernic (As), Chronium (Cr) and Nickel (Ni) in the muscle tissue of catfish which is the part of the fish mostly consumed.

\section{MATERIALS AND METHODS}

Three hundred (300) fingerlings of a month old were purchased and used for this study. They were evenly distributed in 16 aquaria of 10 liters for easy monitoring. They were sacrificed and oven dried initially at a temperature of $110^{0 \mathrm{c}}$ then $65^{\circ \mathrm{C}}$ until a constant weight was obtained. The sample were grinded and $0.5 \mathrm{~g}$ of each were collected and were digest with tri-acid mixture $\left(\mathrm{HNO}_{3}: \mathrm{HClO}_{4}: \mathrm{H}_{2} \mathrm{SO}_{4}:\right.$ 10: 4:1). Digestion was continued until the liquor becomes clear. The samples were analyzed using Atomic Absorption Spectrophotometer. The results were express in mg/l. Metal per dry weight (AAS). The heavy metal contaminations in the dried samples were estimated after acid digestion, following the standard method of APHA (2017).

\section{STATISTICAL ANALYSIS}

Analysis of variance (ANOVA) was used to test for significance different in the levels of heavy metal in the different groups of fishes.

\section{RESULT AND ANALYSIS}

The result of Muscle tissue analyzed shows the availability of the studied heavy metals and its bioaccumulation over a period of three months that the investigation lasted according to standard method of APHA (2017). The result showed that $\mathrm{Mn}$ recorded $896.94 \pm 0.577 \mathrm{mg} / \mathrm{l}$; Co $78.10 \pm 0.577 \mathrm{mg} / \mathrm{l}$ and $\mathrm{Ni}, 78.725 \pm 0.578 \mathrm{mg} / \mathrm{l}$ in feed I and $\mathrm{Mn}$ recorded $506.823 \pm 1.155 \mathrm{mg} / \mathrm{l}$; Co $32.499 \pm 0.577 \mathrm{mg} / \mathrm{l} ; \mathrm{Hg}, 0.001 \pm 0.00001 \mathrm{mg} / 1$; As, $0.006 \pm 0.0000 \mathrm{mg} / 1 ; \mathrm{Cr}, 122.794 \pm 0.577 \mathrm{mg} / 1$. and Ni $56.180 \pm 0.578 \mathrm{mg} / \mathrm{l}$ in feed II as demonstrated in Figure 2. The result of the muscle tissue of male and female C.gariepinus shows the present of heavy metals at different concentration and the highest concentration was observed in female which recorded $44.200 \pm 0.5774 \mathrm{mg} / \mathrm{l}$ of $\mathrm{Ni}$ and the lowest observed in male that recorded $-0.007 \pm 0.0001 \mathrm{mg} / \mathrm{l}$ $\mathrm{Cr}$ as demonstrated in Figure 3.

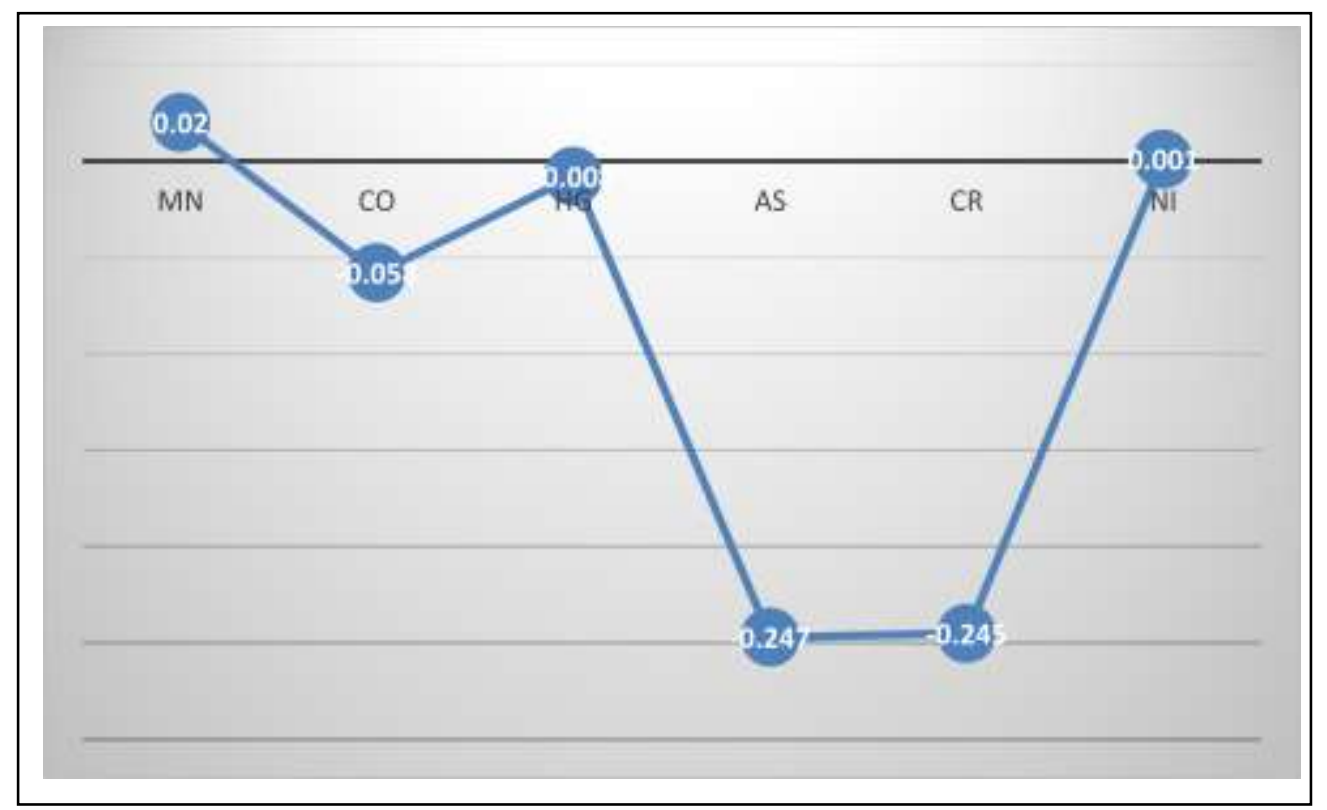

Figure 1: Line graph showing Concentration of Heavy Metals in Used Water

Water $=\mathrm{Mn}>\mathrm{Ni}>\mathrm{Hg}>\mathrm{Co}>\mathrm{As}>\mathrm{Cr}$ 


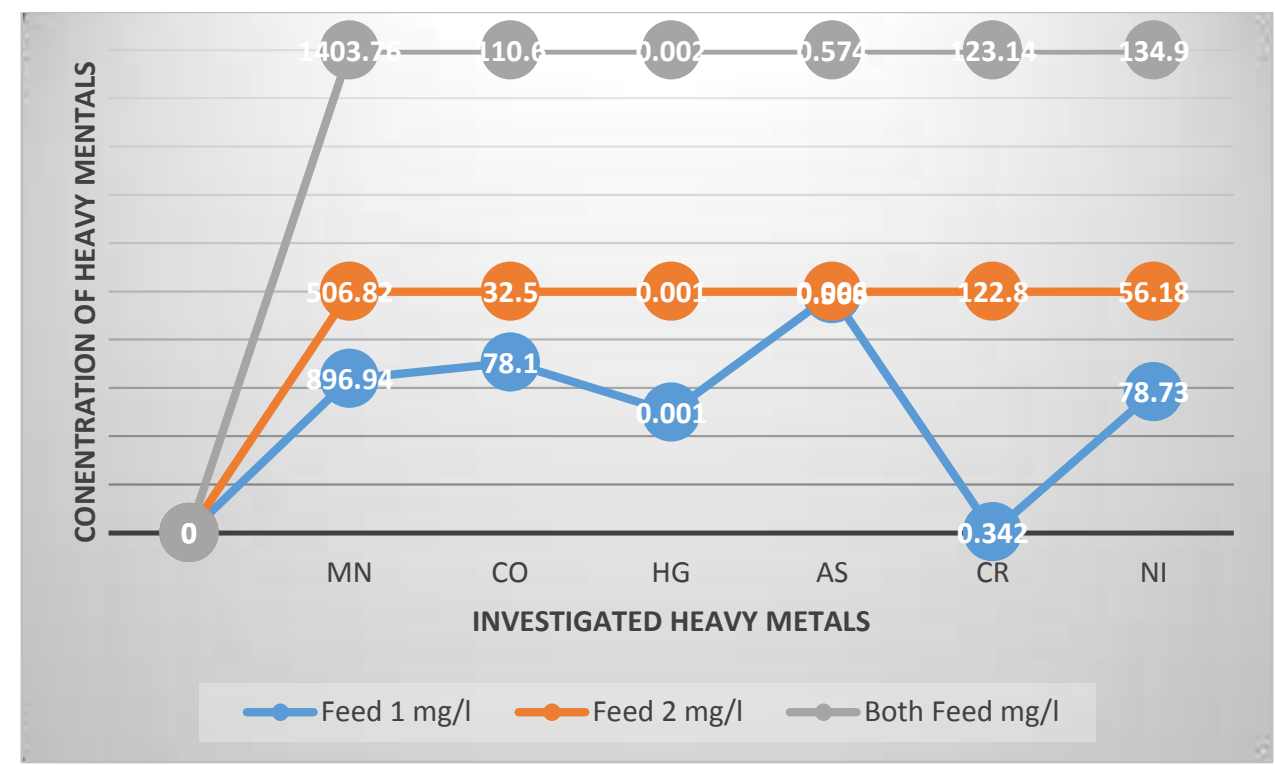

Figure 2: Line Graph showing the Concentration of Heavy Metals in the feed used to Culture the Catfish Feed $\mathrm{I}=\mathrm{Mn}>\mathrm{Ni}>\mathrm{Co}>\mathrm{Cr}>\mathrm{As}>\mathrm{Hg}$ Feed $\mathrm{II}=\mathrm{Mn}>\mathrm{Cr}>\mathrm{Ni}>\mathrm{Co}>\mathrm{As}>\mathrm{Hg}$

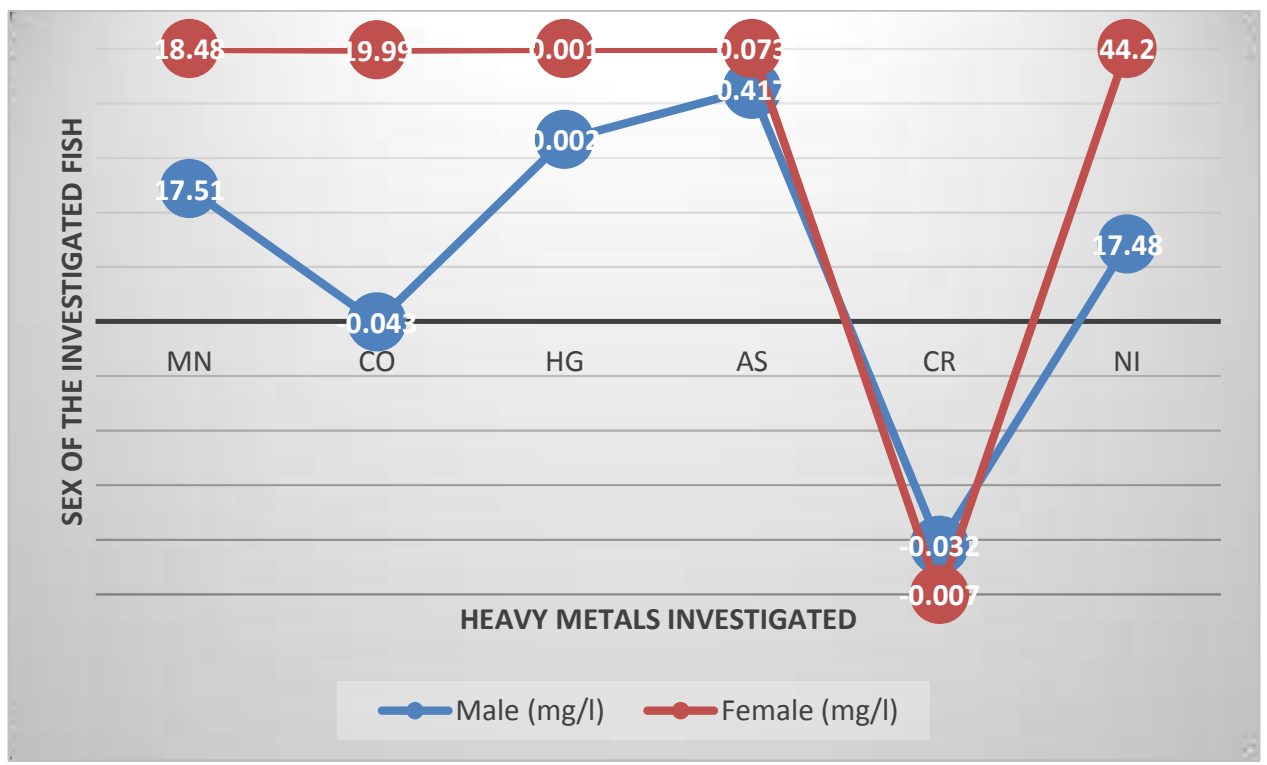

Figure 3: Line Graph showing the Concentration accumulated Heavy Metals in the Muscle

\section{Tissue of Cultured Catfish}

Female $=\mathrm{Ni}>\mathrm{Co}>\mathrm{Mn}>\mathrm{As}>\mathrm{Hg}>\mathrm{Cr}$

Male $=\mathrm{Mn}>\mathrm{Ni}>\mathrm{As}>\mathrm{Co}>\mathrm{Hg}>\mathrm{Cr} \mathrm{Ni}$

\section{DISCUSSION}

Fish have been considered good indicators for heavy metals contamination in aquatic systems. Fish are widely consumed in many parts of the world by humans and polluted fish may endanger human health (Zhang et al., 2007). Heavy metal concentrations in fish muscle tissue can be surmised as one of the most considerable indicators for metal pollution levels in aquaculture. These metals are non-biodegradable and consider as major environmental pollutants causing cytotoxic, mutagenic and carcinogenic effects in animals (More et al., 2003). In human, heavy metals 
accumulation can cause blood and brain related diseases, and it can also affect the function of various body organs such as the liver and kidney.

There was a significant difference ( $\mathrm{P}>0.05)$ among male and female C.gariepinus.

\section{Heavy metals in water}

According to Hidayati et al. (2020) maintaining an acceptable water quality is fundamental in aquaculture for maintaining the vitality and optimal growth of the cultured fish. The results of the heavy metals concentrations in the different water sources and fish ponds presented in Figure 1 were compared to USEPA permissible limits (USEPA 1988) for fish ponds water sources and found safe since they were all below the maximum.

\section{Heavy metals in fed feed}

The concentration of some of the investigated heavy metals in fed commercial feed were found beyond the recommended limit of NOAA (2009) hence not safe to feed the fish. In first feed, Mn was $896.94 \mathrm{mg} / \mathrm{l}$ against the limit that is $400 \mathrm{mg} / \mathrm{l}$, Ni $78.73 \mathrm{mg} / \mathrm{l}$ against $9.90 \mathrm{mg} / \mathrm{l}$, while Co recorded 78.10 against $10.00 \mathrm{mg} / \mathrm{l}$. in the second feed, $\mathrm{Mn}$ was $506.86 \mathrm{mg} / \mathrm{l}$ against $400 \mathrm{mg} / \mathrm{l}$ limit, Cr $122.80 \mathrm{mg} / \mathrm{l}$ against $7-13 \mathrm{mg} / 1$, Ni $56.18 \mathrm{mg} / \mathrm{l}$ against 9.90mg/l while Co recorded $32.5 \mathrm{mg} / \mathrm{l}$ against $10.00 \mathrm{mg} / \mathrm{l}$. this indicated that both commercial feed used were contaminated hence not safe for fish consumption that will translated to final fish consumers.

\section{Heavy metals concentration in fish muscle tissue}

The concentration of heavy metal in muscle tissue of $C$. gariepinus was found safe since they were not beyond the limit in both the female and male. However, Ni was found, beyond the limit in both while Co was in only female fishes. Co $19.99 \mathrm{mg} / \mathrm{l}$ against $10.00 \mathrm{mg} / \mathrm{l} \mathrm{Ni}$ was $44.2 \mathrm{mg} / \mathrm{l}$ against $9.90 \mathrm{mg} / \mathrm{l}$ in female fish and $17.48 \mathrm{mg} / \mathrm{l}$ against $9.90 \mathrm{mg} / \mathrm{l}$ in male fish.

\section{CONCLUSION AND RECOMMENDATION}

This study has proved the availability of $\mathrm{Mn}, \mathrm{Co}, \mathrm{Hg}, \mathrm{As}, \mathrm{Cr}$ and $\mathrm{Ni}$ in the muscle tissue of C.gariepinus and also in the water and feeds used in the culturing of the fish. This metal concentration observed in muscle tissue, feeds and water was beyond the maximum permissible limit by FAO, FEPA and WHO for human consumption contrary to most view that bioaccumulation of heavy metals is related to environmentally polluted water. Based on these findings, it is recommended that proper quality control analysis should be carried out in the cultured fish to determine it safety before human consumption.

\section{REFERENCES}

APHA (2017). Standard methods for the examination of water and wastewater, 23rd edn. American Public Health Association

Bawuro, A. A., Voegborlo, R. B. and Adimado, A. A. (2018). Bioaccumulation of heavy metals in some tissues of fish in Lake Geriyo, Adamawa State, Nigeria. J Environ Public Health 2018:1-7. https://doi.org/ $10.1155 / 2018 / 1854892$

Das, P.R., Hossain, M.K., Sarker, B.S., Parvin, A., Das, S.S., Moniruzzaman, M. and Saha, B. (2017) Heavy Metals in Farm Sediments, Feeds and Bioaccumulation of Some Selected Heavy Metals in Various Tissues of Farmed Pangasius hypophthalmus in Bangladesh. Fisheris and Aquaculture Journal 8: 218. doi:10.4172/21503508.1000218

Duruibe, J. O., Ogwuegbu, M. O. C. and Egwurugwu, J. N.(2007). Heavy metal pollution and human biotoxic effects. International Journal of Physical Sciences; 2(5):112-118.

Halla E. K. El Bahgy1,2 \& Hiam Elabd3 and Reham M. Elkorashey (2021). Heavy metals bioaccumulation in marine cultured fish and its probabilistic health hazard Environmental Science and Pollution Research., https://doi.org/10.1007/s11356-021-13645-8 
Hidayati, N.V., Prudent, P., Asia, L., Vassalo, L., Torre, F., Widowati, I., Sabdono, A., Syakti, A.D. and Doumenq, P. (2020). Assessment of the ecological and human health risks from metals in shrimp aquaculture environments in Central Java, Indonesia. Environ Sci Pollut Res 27: 41668-41687. https://doi.org/10.1007/s11356-020-09967-8

NOAA (2009) SQUIRT, Screening Quick Reference Table for in Sediment.

Okwuosa, O. B. (2011). "Catfish Technology and Business Manual”. Lousiis Chumez Enterprise, Nsukka, Enugu state, Nigeria. ISBN: 978-36275-5-0 pg 46

Sen, I., Shandil, A., and Shrivastava, V. (2011). Study for determination of heavy metals in fish species of the river Yamuna (Delhi) by inductively coupled plasma-optical emission spectroscopy (ICP-OES). Advances in Applied Science Research 2: 161-166.

Staniskiene, B., Matusevicius, P., Budreckiene, R. and Skibniewska, K.A. (2006) Distribution of heavy metals in tissues of freshwater fish in Lithuania. Pol J Environ Stud 15: 585-591.

USEPA (1988). Water quality standards criteria summaries: a compilation of State/Federal Criteria | US Environmental Proteection Agency. In: Washington, DC

WHO/FAO (1989). National Research Council Recommended Dietary 626 Allowances (10th ed). World Health Organization / Food and Agriculture Organization for United States, Washington, DC, USA

\section{Correspondence Author: Okwuosaobinnaben@gmail.com}

